Supplement of Clim. Past, 16, 1007-1025, 2020

https://doi.org/10.5194/cp-16-1007-2020-supplement

(c) Author(s) 2020. This work is distributed under

the Creative Commons Attribution 4.0 License.

(c) (1)

Supplement of

\title{
Can morphological features of coccolithophores serve as a reliable proxy to reconstruct environmental conditions of the past?
}

\section{Giulia Faucher et al.}

Correspondence to: Giulia Faucher (giulia.faucher@unimi.it)

The copyright of individual parts of the supplement might differ from the CC BY 4.0 License. 


\section{S1 Geological background}

Several authors tried to link nannofossil morphological variations with detected environmental conditions: the process assumes to analyze nannofossil species through a sedimentary succession and to evaluate the presence of shape or size anomalies in the considered interval of time. The eventual detected morphological variations are then linked to independent paleo-

5 environmental data (e.g. sea surface temperature reconstruction $(\mathrm{SST}), \mathrm{CO}_{2}$ ) to find the environmental driver for the identified morphological variation

Indeed, the past oceans were characterized by episodes of anomalous or extreme sea-water conditions that could have possibly influenced the phytoplanktonic communities. A good example is the oscillations between "calcite seas" and "aragonite seas" (Sandberg, 1983) that possibly influenced the productivity of calcareous nannoplankton at different times (Erba, 2006). The

10 amount of massive amount of chalk deposited during the Late Cretaceous is a good illustration of a high productivity time for calcareous nannoplankton probably permitted by a shift in seawater chemistry towards a very high level of Ca. In parallel, rising $\mathrm{Mg} / \mathrm{Ca}$ ratio during the Cenozoic and up to present days is correlated to a reduction in coccolithophore diversity and coccolith thickness (Bown et al., 2004). Also, locally, light could have played a major role for coccolithophore calcification in the past ocean: it was documented that during episodes of intensified continental weathering, more clastic particles were

15 transported into the sea and in the coastal area might have diminished the depth of the photic zone (Lechler et al., 2015). The reduction in light availability was associated with habitat changes of the photoautotrophic primary producers that produced smaller coccoliths to be able to dwell in shallower depth and compensate for the reduction in sunlight (Lübke and Mutterlose, 2016). The calcareous phytoplanktonic communities in past oceans were also disturbed by intervals with excess $\mathrm{CO}_{2}$ concentrations related to intense volcanic activity. Modifications in size and morphology of calcareous nannofossil during

20 times were $\mathrm{CO}_{2}$ reached up to 1000-2000 ppm, were interpreted as a transient response to survive progressively increasing surface-water acidification (Erba et al., 2010, Lübke et al., 2015; Faucher et al., 2017). Besides, environmental constraints for calcareous nannoplankton growth, involve the ocean trophic level: in the fossil record, some authors linked the decrease in nutrient availability, with reductions of abundances and sizes of some calcareous nannofossil species (Linnert and Mutterlose, 2012). Other authors, on the contrary, detected similar size reductions in several ocean areas characterized by both oligotrophic

25 and mesotrophic seawater conditions (Bornemann et al., 2006; Faucher et al., 2017). Finally, the ocean in its history was subjected to variation in temperature: a strong hydrothermal activity on one hand and an intense continental weathering, on the other hand, were the main triggers of respectively $\mathrm{CO}_{2}$ released and $\mathrm{CO}_{2}$ sequestration, that in turns, often produced a concomitant increase or decrease in SST. Episodes characterized by relatively low SST were sometimes related to small coccolith sizes (Bornemann and Mutterlose, 2006). However, opposite behaviors were also observed (size decreases under

30 extremely warm conditions, Erba et al., 2010; Lübke et al., 2015) in the same species in different geological intervals.

\section{References:}


Bornemann, A. and Mutterlose J.: Size analyses of the coccolith species Biscutum constans and Watznaueria barnesiae from the Late Albian “Niveau Breistroffer”(SE France): taxonomic and palaeoecological implications, Geobios, 39(5), 599-615, 35 https://doi.org/10.1016/j.geobios.2005.05.005, 2006.

Bown, P. R., Lees, J. A., Young, J. R.: Calcareous nannoplankton evolution and diversity through time, in: Coccolithophores, edited by: Thierstein, H.R., Young, J.R., Springer Berlin Heidelberg, Germany, 481-508, 2004.

Erba, E.: The first 150 million years history of calcareous nannoplankton: biosphere-geosphere interactions, Palaeogeography, Paleoclimatology, Paleoecology, 232, 2, 237-250, https://doi.org/10.1016/j.palaeo.2005.09.013, 2006.

40 Erba, E., Bottini, C., Weissert, H. J., Keller, C. E.: Calcareous nannoplankton response to surface-water acidification around Oceanic Anoxic Event 1a, Science, 329(5990), 428-432, https://doi.org/10.1126/science.1188886, 2010.

Faucher, G., Erba, E., Bottini, C., Gambacorta, G.: Calcareous nannoplankton response to the latest Cenomanian Oceanic Anoxic Event 2 perturbation, Rivista Italiana di Paleontologia e Stratigrafia (Research In Paleontology and Stratigraphy), 123(1), 2017a.

45 Lechler, M., von Strandmann, P. A. P., Jenkyns, H. C., Prosser, G., \& Parente, M.: Lithium-isotope evidence for enhanced silicate weathering during OAE 1a (Early Aptian Selli event). Earth and Planetary Science Letters, 432, 210-222, https://doi.org/10.1016/j.epsl.2015.09.052, 2015

Linnert, C., Mutterlose, J.: Biometry of Cenomanian-Turonian placoliths: a proxy for changes of fertility and surface-water temperature? Lethaia, 46(1), 82-97, https://doi.org/10.1111/j.1502-3931.2012.00323.x, 2012.

50 Lübke, N. and Mutterlose, J.: The impact of OAE 1a on marine biota deciphered by size variations of coccoliths, Cretaceous Research, 61, 169-179, https://doi.org/10.1016/j.cretres.2016.01.006, 2016.

Lübke, N., Mutterlose, J., Bottini, C.: Size variations of coccoliths in Cretaceous oceans, a result of preservation, genetics and ecology? Marine Micropaleontology, 117, 25-39, https://doi.org/10.1016/j.marmicro.2015.03.002, 2015.

Sandberg, P. A.: An oscillating trend in Phanerozoic non-skeletal carbonate mineralogy. Nature, 305(5929), 19-22, 1983.

\section{S2 Growth rate}

Samples for cell abundance were taken at the end of the experiment with the exception of the nutrient experiments where samples were taken every second day. Incubation bottles were turned to resuspend all cells and to obtain a homogenous suspension of the cells before sampling. Cell numbers were immediately measured three times without addition of

60 preservatives using a Beckman coulter Multisizer. Specific daily growth rates $(\mu)$ were calculated as:

$\mu=\frac{\ln c 1-\ln c 0}{t 1-t 0}$ 
where $\mathrm{c} 0$ and $\mathrm{c} 1$ are the cell concentrations at the beginning ( $\mathrm{t} 0)$ and at the end of the incubation period ( $\mathrm{t} 1)$, respectively. Growth rate data were used to check the growth phase of the species.

\section{S2.1 Light}

65 Emiliania huxleyi growth rates followed an optimum curve response pattern along the light gradient and the optimum growth rate was recorded at $450 \mu \mathrm{mol}$ photons $\mathrm{m}^{-2} \mathrm{~s}^{-1}$ (Fig. S1; Table 2). Gephyrocapsa oceanica, C. braarudii and P. carterae growth weren't influenced by light intensity. P. carterae displayed increasing growth rates at higher light intensities. All data are reported in Table 2 and shown in Fig. S1.

\section{$\mathrm{S} 2.2 \mathrm{Mg} / \mathrm{Ca}$}

70 Emiliania huxleyi, G. oceanica and C. braarudii growth rates were negatively influenced by increasing [Ca ${ }^{2+}$ ] while no effect was observed on P. carterae growth (Fig. S2; Table 3).

\section{S2.3 Nutrient}

In the $\mathrm{N}$ and $\mathrm{P}$ limited treatments, E. huxleyi growth rate was $58 \%$ and $71 \%$ lower than in the (nutrient replete) control treatment (Fig. S3; Table 4). Gephyrocapsa oceanica growth rate in N and P limited treatments was $76 \%$ and $43 \%$ lower (Fig. S3).

75 Coccolithus braarudii growth rate was $82 \%$ and $69 \%$ lower. Pleurochrysis carterae did not grow in the P limited conditions. $\mathrm{N}$-limitation reduced growth rate compared to the control by $50 \%$.

\section{S2.4 Temperature}

Elevated temperature, accelerated growth rates in E. huxleyi and G. oceanica by 50 and $75 \%$, respectively. Pleurochrysis carterae growth rates declined by about $30 \%$ at $22.5^{\circ} \mathrm{C}$ relative to $15^{\circ} \mathrm{C}$. Coccolithus braarudii did not grow at $22.5^{\circ} \mathrm{C}$ (Fig.

80 S4; Table 5).

\section{S2.5 Carbonate chemistry}

Emiliania huxleyi growth rate was significantly lower in the OA and CS2 treatments compared to the control and the CS1 treatment. (Fig. S5, Table 6). Gephyrocapsa oceanica growth rate was reduced in the OA, CS1 and CS2 treatment compared to the control with the lowest rate observed in the CS2 treatment. Coccolithus braarudii growth was reduced in the OA, CS1

85 and CS2 treatments compared to the control. Pleurochrysis carterae growth rate was unaffected by changing carbonate chemistry. 


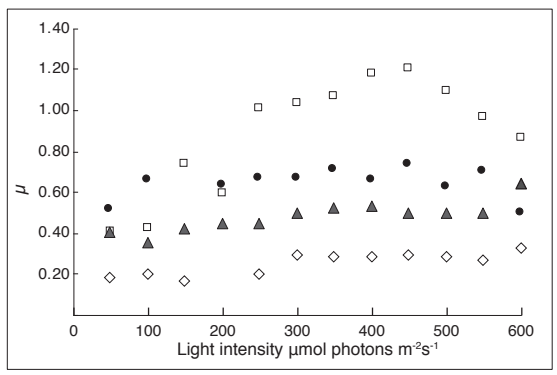

90 Figure S1: Average growth rate under different irradiances. Square: E. huxleyi; dot: G. oceanica; triangle: C. braarudii ; diamond: P. carterae.

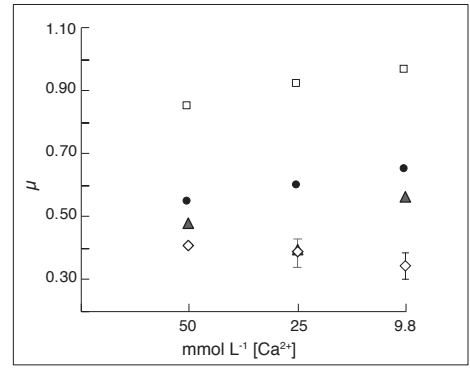

Figure S2: Average growth rate under different Mg/Ca conditions; all measurements were done in triplicates; error bars denote standard deviations. If not visible, error bars are smaller than symbols. Symbols: square: $E$. huxleyi; dot: G. oceanica; triangle: $C$. braarudii ; diamond: $P$. carterae.

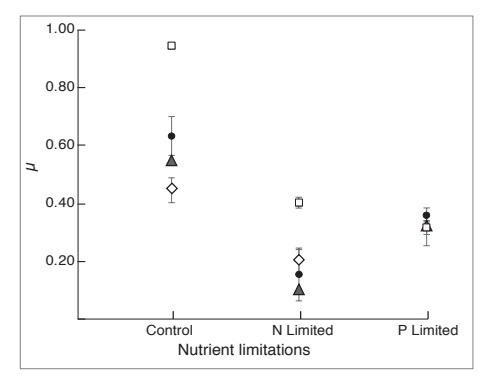

Figure S3: Average growth rate under different nutrient conditions; all measurements were done in triplicates; error bars denote standard deviations. If not visible, error bars are smaller than symbols. Symbols: square: $E$. huxleyi; dot: G. oceanica; triangle: $C$. braarudii ; diamond: $P$. carterae; $P$. carterae didn't grow under $P$ limited regime. 


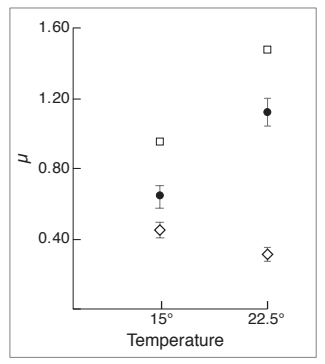

Figure S4: Average growth rate under different temperature conditions; all measurements were done in triplicates; error bars denote standard deviations. If not visible, error bars are smaller than symbols. Symbols: square: $E$. huxleyi; dot: G. oceanica; diamond: $P$. carterae.

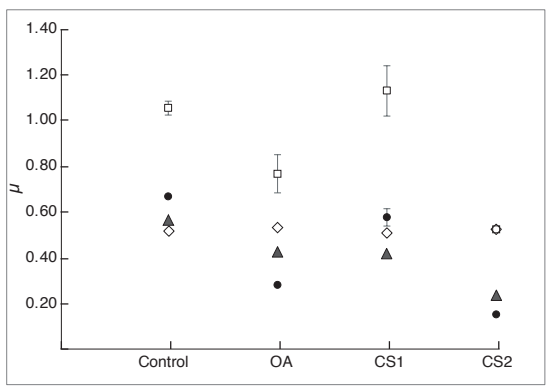

Figure S5: Average growth rate under different carbonate chemistry conditions; all measurements were done in triplicates; error bars denote standard deviations. If not visible, error bars are smaller than symbols. Symbols: square: E. huxleyi; dot: G. oceanica; triangle: $C$. braarudii; diamond: $P$. carterae.

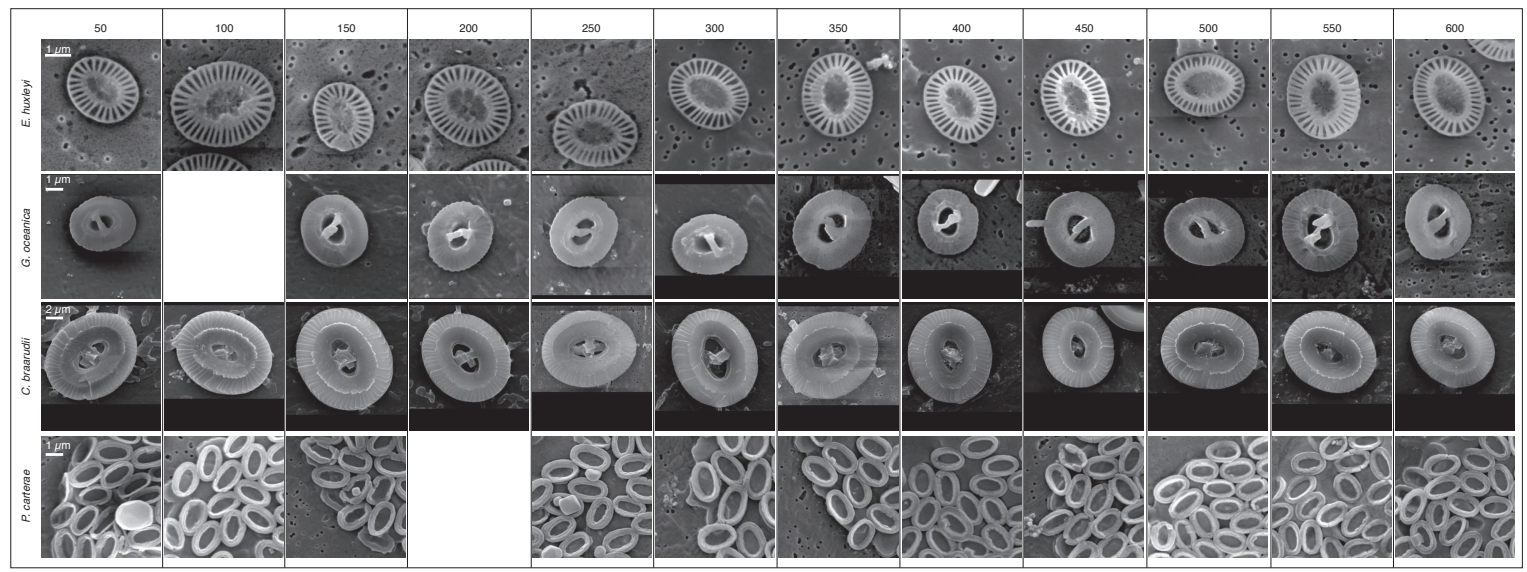


Plate 1: Example of coccoliths of the four tested species under different light intensities

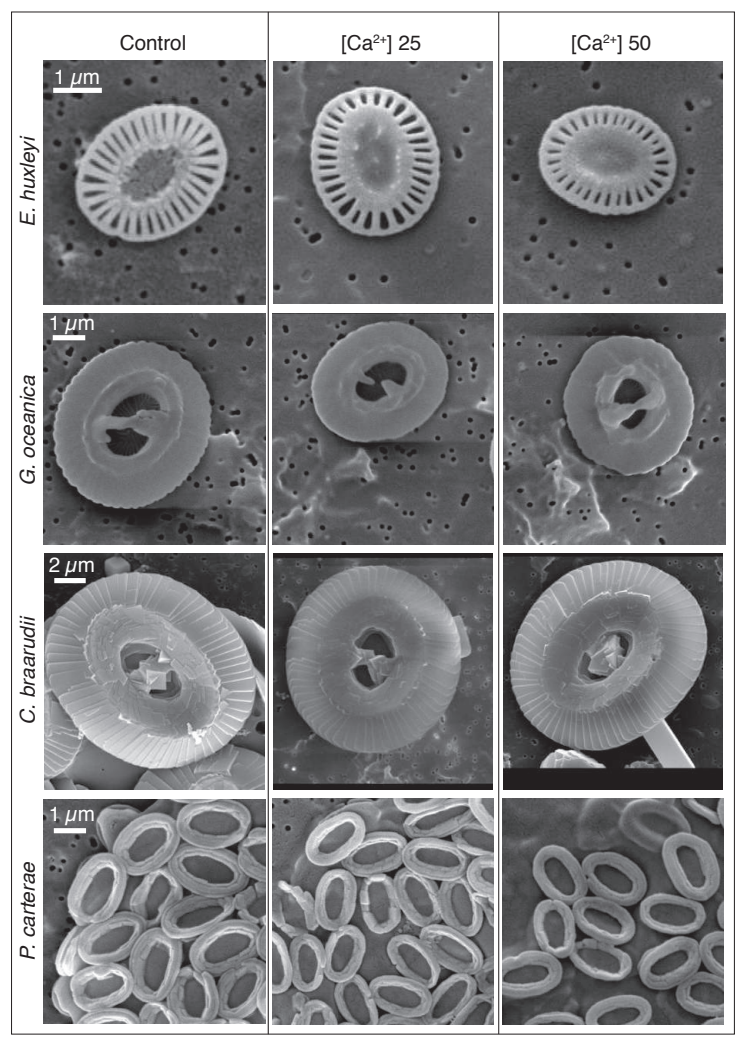

115 Plate 2: Example of coccoliths of the four tested species under different Ca concentrations 


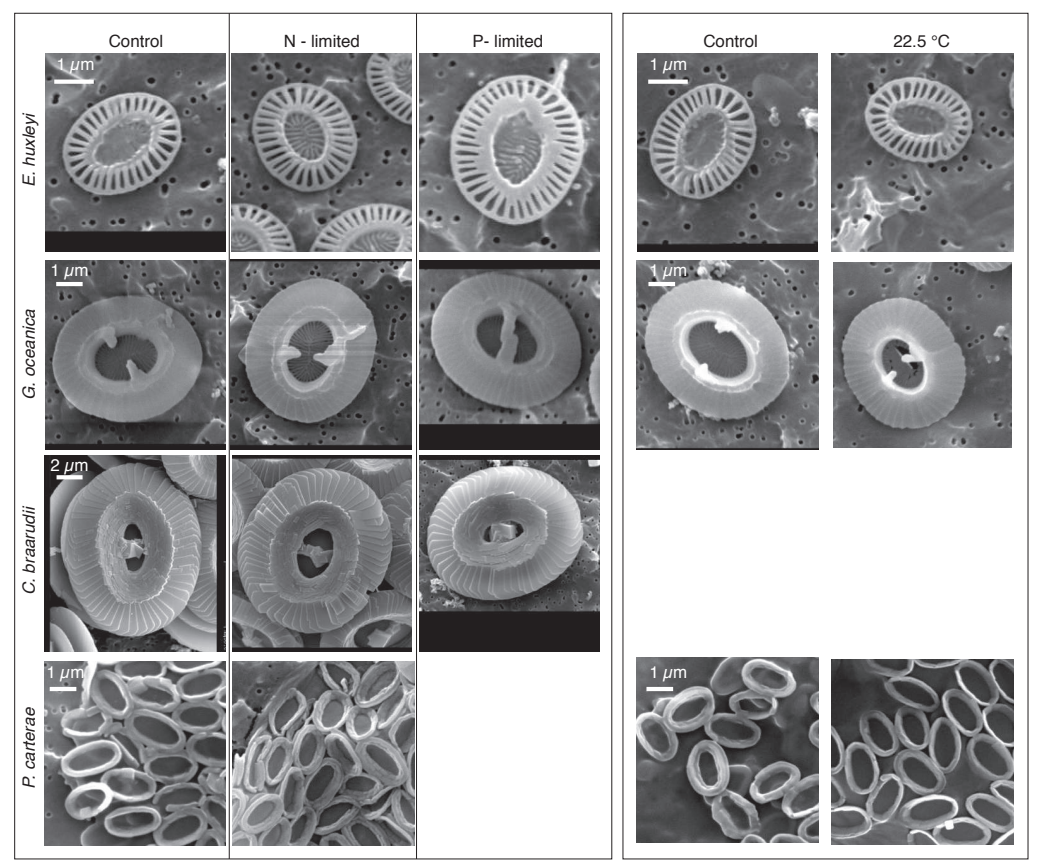

Plate 3: Example of coccoliths of the four tested species under different nutrient conditions and temperature values. 


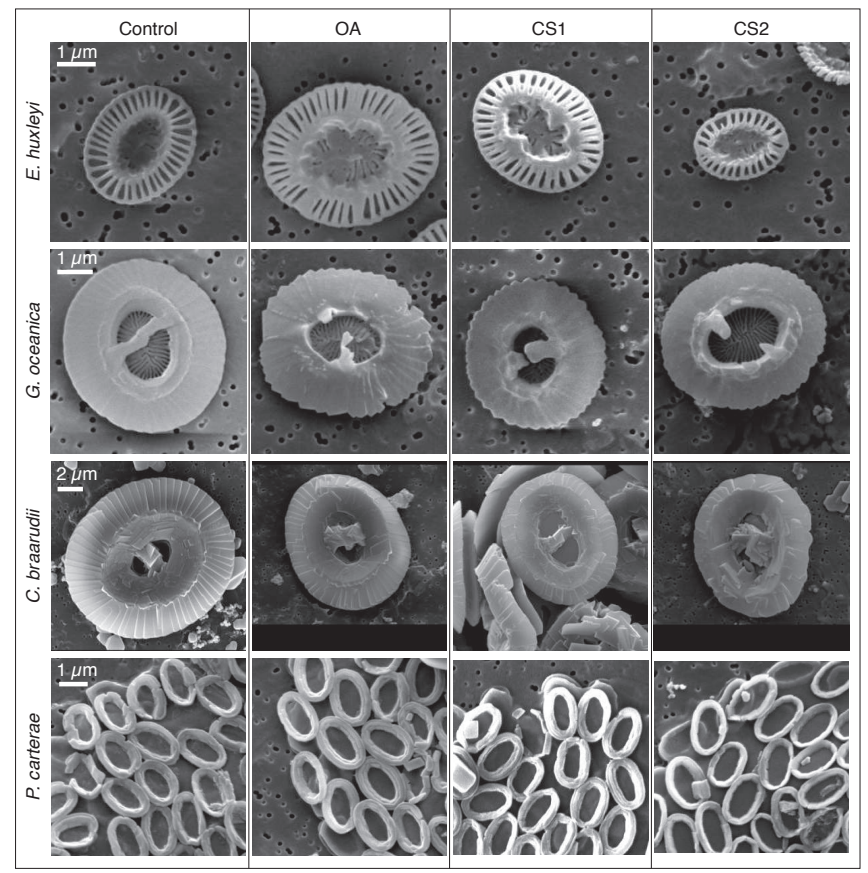

Plate 4: Example of coccoliths of the four tested species under different $\mathrm{CO}_{2}$ concentrations 